\title{
An Analysis of Educational Values and Character Values in Novel Selena by Tereliye and Their Implication for Learning High School
}

\author{
Siti Sundari ${ }^{\left.1^{*}\right)}$, Missriani ${ }^{2}$, Yessy Fitriani ${ }^{2}$ \\ ${ }^{1}$ SMA Negeri 1 Muaradua \\ ${ }^{2}$ Universitas PGRI Palembang \\ *Corresponding author. E-mail: sundarisiti218@gmail.com
}

\begin{abstract}
The aim of this article was to describe the educational value contained in Tere Liye's Selena novel, to determine the character of the characters in Tere Liye's Selena novel, and to determine the implications of educational value and character of Tere Liye's Selena's novel on literary learning in High school. The article was library research and using documentation as collecting data. The data source of this research was the novel Selena by Tere Liye. Data collection techniques in this study by means of direct observation and external documentation. The results of the analysis prove that in Tere Lie's novel Selena there are 12 aspects of religious values, moral values, 28 aspects, social values, 10 aspects and 2 social values. Selena novel by Tere Liye is suitable to be read and used as reading material in literature learning in high school.
\end{abstract}

Keywords: Educational Value, Educational Character, Tere liye Novel

\section{INTRODUCTION}

Literature is not just plain words without meaning and without value. Literature is actually a tool that is able to convey something that is also able to influence readers and listeners. In addition to having a role in the process of transferring information from the author to the reader, literary works also play a role as text created by the author and as text that is perceived by readers [1]. One that can be transferred by an author in his literary work is the value of education. Educational values are useful things in an effort to provide changes to better attitudes and behavior [2]. Simare mare, Ronny Franto argues that the educational values contained in novel literary works are: The value of religious education related to religion and the relationship between humans and their gods; The value of moral education related to human good and bad behavior in life; The value of social education related to the relationship between human society and other humans; as well as the value of cultural education related to habits, customs, and habits in social life [3].

Character is a collection of the good behavior of a human child; this behavior is a manifestation of the awareness of carrying out roles, functions, and duties to carry out the mandate and responsibility [4]. Meanwhile, the reverse character indicates a number of bad traits of a person.

Nashir asserted that characters are differentiated into main characters and optional characters. The main character was a character that becomes the foundation for the chosen character, whatever the profession [5]. The main characters include basic character, superior character, and leader character [6]. The basic characters consist of three characteristics, namely selflessness, honesty, and discipline. Superior character consists of seven good qualities, namely sincerity, patience, gratitude, responsibility, sacrifice, self-improvement, and being sincere. Leader's character includes nine traits, namely fair, wise, wise, knightly, tawadhu, simple, visionary, solution, communicative, and inspirational. Meanwhile, the character of choice is good behavior that develops inherent in the work profession [7], each of which has a different teacher character from the military character according to the profession. The development of a character's character is influenced or even shaped by the background that surrounds him [8]. It also means that the character of a character can be understood through and at the same time made clear by the conditions of the setting that raised him [9]. 
According to Rafiek, the characters can be expressed in two ways, namely direct and indirect ways [10]. The explanation as follows; The first Analytical way; the analytical method is that the author explains or tells directly describe. The author clearly shows or describes the character's character. The second was Dramatic way. The dramatic way is to express the character's character indirectly through the storyline. So, character is not described and described immediately, but is covertly expressed through stories. Based on the above background, the researcher conducted a research entitled Analysis of Educational Values and Character Characters in Tere Liye's Selena Novel and its Implications for Literature Learning in High School.

\section{METHODS}

This research focus on describe the educational values and character of the characters in Tere Liye's novel Selena and their implications for learning literature in high school. The article was library research and using documentation as collecting data. The data source of this research was the novel Selena by Tere Liye. The collecting data was carried out by reading various library materials which are closely related to the problem to be studied. The data obtained is in the form of materials or information relating to the problem, namely the elements of educational value and the character of the novel Selena.

In analyzing data the researchers used content analysis that consist of read literary works, master the theory, Master the method, search and find data. analyze the data, analysis the data, make improvements, and give the conclusions.

\section{RESULTS AND DISCUSSION}

Selena's novel is the latest novel from Tere Liye. This novel is a novel that can be used as a reference in literature learning in high school. [11] The main character of this novel is named Selena. This figure has inspired a lot in education. The manifestation of the value of education is contained in several dialogues or quotes from the novel entitled Selena. The value of education can be seen in the following quotations.

Religious Value. In this case [12] contains religious values. For example, when Selena is leaving for her uncle Togra, who gives a prayer as a form of submission to God about Selena's fate to find a better life. That is the only prayer delivered by Aunt Gill, a lecturer in the Night and Mystery course. Aunt Gill also prayed for Selena as a form of surrender to God. This can be seen in the following quote.

I smiled broadly. Yes! Clenched fists. Looking up, the sky started shedding raindrops. Around me was immediately wrapped in drops of water [13]. My face is wet, my curly hair, my clothes. I completely ignore Aunt GiII's most important sentence: May it lead you to the path of goodness not the other way around, because a scout is very close to the path of darkness [14]

The Value of Moral Education. One of the moral attitudes is honesty in attitude. Selena just harbored a sense of pride. Selena's father and mother didn't feel proud, but Aunt Leh was very proud of Selena. He always supports Selena's ideals. This can be seen in the following quote.

"If that's your goal, then do whatever makes you welcome there, Selena. It is your right. Do not hesitate. Your mother Jem would be very proud if she could see her son accepted into the best campus of the entire Moon Clan. I lifted my head. Looked back at Auntie Leh. The three years I lived in this house, Aunt Leh always supported me. Aunt Leh never asked many questions, she always trusted me. I nodded firmly [15].

From the quotation above, it can be explained that Aunt Leh's authentic moral attitude has always supported [16]. Aunt Leh believes that Selena's high goal is to improve her life situation for the better.

The Value of Social Education The value of social education is a value that is widely found in Tere Liye's novel Selena. There are three values of social education, the first is the value of compassion, the second is the value of responsibility, and the third is the value of life escapism. The value of compassion is a feeling that sincerely comes from the heart and contains a desire to give, love, care for and be happy. This can be seen in the following quote.

"I know your mother has absolutely no money. But your neighbors are kind, they have raised money for your trip to the capital, Selena." Togra held out a red envelope - as if he knew what I was thinking while looking down. I accept it. "Not much. But that's enough until you get there". "Thank you. I said softly. (Selena: 5-6). From the quote above, it can be explained that the social value in the form of affection is shown by Togra, who represents his neighbor. They sympathize and show their affection for Selena for the death of Jem, Cultural Education Value. The novel Selena by Tere Liye has the value of cultural education, although the value of cultural education is not as much as the value of moral education and social education. The value of cultural education can be divided into two, namely cultural values in the relationship between humans and God. These values are shown in the following quote. Cultural education in this respect has been violated by Selena. This can be seen in the following quote.

"My name is Av. I'm the head of the Central 
Library. "The old man touched my arm softly. Instantly, there was a feeling of warmth running through my arm, making me calmer, happier, hard to explain. "What's your name, young lady?" "Jem." I lied. The old man smiled again. "What are you trying to find in this Forbidden Section, Jem? You're trying to break in. It was a brave and desperate act. Not even a thousand members of the Shadow Army can pass through this tunnel".

From the above quote it can be explained that Selena has violated a forbidden section of the central library. Furthermore, Selena was also forced to lie by mentioning her mother's name when Av the head of the library asked her name.

If viewed from the way the author presents the characters, it can be explained that Selena's novel uses a dramatic way of presenting character characters. The dramatic way is to express the character's character indirectly through the storyline.

Tere Liye tells the characters in a covert, which is first seen from the author's speech to the character of the perpetrator. Many things show the author's speech towards the character of the perpetrator.

The author's speech regarding the character of the perpetrator is conveyed indirectly through the main character, namely Selena. Selena is described by the author as a girl who has the advantage of remembering everything she has ever seen.

The author wants to convey that the main character in the novel is an orphaned child. Besides that, it can also be seen based on how the character talks about himself, understanding how his thoughts are going. Apart from this, it can be seen from other figures who talk to him. Dramatic character characters can also be seen based on seeing other characters about him.

The character of the character is expressed by looking at another character about Selena, the author wants to explain that Raf has a nephew named Selena who masters the techniques of the Moon clan and his intelligence is enough to make two engineers amazed at Selena. In addition, the character of the character Selena is depicted in a dramatic way by seeing how the other characters react to her.

The author mentions the character of Selena as a character who has the advantage of reading complex calculations. This can be seen from the reaction of $\mathrm{Aq}$ and two engineers. Likewise, the character of a character is described analytically by the author by seeing how the character reacts to other characters. Thus, it can be said that the character of Selena is described by the author in an analytic way.

Implications of Educational Values and the character of Tere Liye's novel Selena on Literature Learning in SMA. In this connection, reviewers can use moral or educational studies. These two things cannot be separated from each other. According to Understanding drama in an educational context is the same as reflecting on what education is contained in the drama. Apart from dialogue, the educational aspect, novel learning, tends to emphasize the emotional aspect. This is because in novel learning there is patience, concentration, and thoroughness, which supports the perfection of the novel.

In connection with learning in high school, the researcher implied a structural study of the halfsalmon human novel on the learning activities of Indonesian for class XII Semester 1, basic competence 3.9 Analyzing novel content and language and 4.9 Designing novels or novelettes with attention to content and language.

Other research also found that character education was a system of inculcating character values which includes components knowledge, awareness, willingness, and actions to carry out values [17][18], both against God Almighty, neighbor, environment, and environment so that they become human beings kamil. Character education can be integrated in learning in every subject [19]. Learning materials related to norms or values in each subject needs to be developed, made explicit [20], in the context of the context of everyday life. Thus, learning character values is not only at the cognitive level, but at the supervisory level on internalization and real experience in the daily life of students in society.

Character education aims to improve the quality of educational processes and outcomes leads to character education and noble morals of the learner as a whole, integrated, and balanced [21], in accordance with the competency standards of graduates in each educational unit [22][23]. Through learner character education is expected to be able to independently improve and use his knowledge, examine, and internalize, and personalize values of character and noble morals so that they are manifested in daily behavior. Hence, Individuals with good character are individuals who can make decisions and are ready to take responsibility for any consequences the decision [24][25]. Character can be considered as the values of human behavior that are related with God Almighty, self, fellow human beings, environment, and nationalit manifested in thoughts, attitudes, feelings, words, and actions based on norms religion, law, karma, culture, customs, and aesthetics

The implications of this research are as follows: Selena's novel by Tere Liye is a motivation that education can be done if you have a strong desire and make serious efforts. The characters in Selena's novels and can be obtained as examples in learning and in everyday life. This novel contains a lot of 
educational value but care needs to be taken for the teacher to be able to explain and adapt this story, Tere Liye with her imagination brings the reader to the imagination, and thinks of the technology that Tere Liye imagined.

\section{CONCLUSION}

The results of this research show that the educational value contained in the novel Selena by Tere Liye was the value of religious education, the value of moral education, the value of cultural education. The characters in the novel Selena by Tere Liye are expressed by the author in a dramatic way. This can be seen from the author's speech to the character of the perpetrator, seeing how the character talks about himself. Understand how the way his thoughts are, see other characters talking to him, see other characters about him, see how the other characters react to him, see how that character reacts to other characters, through what he does, through his words, and through physical depiction of characters. The researcher concluded that the novel Selena by Tere Liye has educational values so it is suitable to be read and used as reading material in literature learning in high school.

\section{REFERENCES}

[1] Sugihastuti, (2010). Teori Apresiasi sastra. Jogjakarta: Pustaka Pelajar.

[2] Said, A., \& Muslimah, M. (2021). Evaluation of Learning Outcomes of Moral Faith Subjects during Covid-19 Pandemic at MIN East Kotawaringin. Bulletin of Science Education, 1(1), 7-15.

[3] Simare M., Ronny Franto. (2014). Skripsi: Nilai-Nilai Pendidikan pada Novel 9 Matahari Karya Adenita. Bengkulu. Universitas Bengkulu

[4] Amri, S., Ismawati, T., \& Armila, A. (2020). Studi Analisis Nilai Nilai Pendidikan Karakter Perspektif Syech Muhammad Khudhari Bek dalam Kitab Khulashah Nurul Yakin. Attractive: Innovative Education Journal, 2(2), 77-88

[5] Nashir, H. (2013). Pendidikan Karakter Berbasis Agama dan Kebudayaan. Yogyakarta: Multi Presindo

[6] Syaikhoni, Y., Subandi, S., \& Fadillah, K. (2021). The Implementation of Student Discipline Character through School and Parents' Collaboration. Bulletin of Pedagogical Research, 1(1), 174-186.

[7] Cahyono, H., Suhono, S., \& Khumairo, A. (2018). Pendidikan Karakter Bagi Pelaku Pedofilia (sebuah Strategi dalam Mengatasi Amoral). JMKSP (Jurnal Manajemen,
Kepemimpinan, dan Supervisi Pendidikan), 3(1), 1-19.

[8] Nurgiyantoro, B. (2010). Teori Pengkajian Fiksi. Yogyakarta: Gadjah Mada University Press.

[9] Cahyono, H., Suhono, S., \& Khumairo, A. (2018). Pendidikan Karakter Bagi Pelaku Pedofilia (sebuah Strategi dalam Mengatasi Amoral). JMKSP (Jurnal Manajemen, Kepemimpinan, dan Supervisi Pendidikan), 3(1), 1-19.

[10] Rafiek, M. (2013). Pengkajian Sastra: Kajian Praktik. Bandung: Refika Aditama.

[11] Setiawan, Adi., Emi Agustina, \& Yayah Chanafiah. Analisis Tokoh Utama dalam Novel Rose in The Rain Karya Wahyu Sujani. https://ejournal.unib.ac.id/index.php/korpus/issu e/archive

[12] Nurlaili, Siti. (2017). Perilaku Tokoh dan NilaiNilai Pendidikan Karakter dalam Novel Pasung Jiwa Karya Okky Madasari dan Implikasinya Dalam Pengembangan Bahan Ajar Sastra di SMA. http://digilib.unila.ac.id/27494/

[13] A, Teeuw. (2013). Sastra dan Ilmu Sastra: Pengantar Teori Sastra. Jakarta: Dunia Pustaka Jaya.

[14] Pradopo, Rahmad Djoko. (2017). Teori Kritik dan Penerapannya dalam Sastra Indonesia Modern. Gajah Mada University Press.

[15] Pratiwi, Lili. (2019). Nilai-nilai pendidikan karakter dalam novel karya habiburrahman el shirazy. Disertasi thesis, universitas islam negeri sultan syarif kasim riau. http://repository.uinsuska.ac.id/21131/.

[16] Rokhmansyah, Alfian. 2014. Studi dan Pengkajian Sastra. Yogyakarta : Graha Ilmu.

[17] Ramdhani, M. A. (2017). Lingkungan pendidikan dalam implementasi pendidikan karakter. Jurnal Pendidikan UNIGA, 8(1), 2837.

[18] Putra, M. A. H. (2019). Building Character Education Through The Civilization Nations Children. The Kalimantan Social Studies Journal, 1(1), 12-17

[19] Sugiyo, R., \& Purwastuti, L. A. (2017). Local wisdom-based character education model in elementary school in Bantul Yogyakarta Indonesia. Sino-US English Teaching, 14(5), 299-308

[20] Khaidir, E., \& Suud, F. M. (2020). Islamic education in forming students' characters at asshofa Islamic High School, pekanbaru Riau. International Journal of Islamic Educational Psychology, 1(1), 50-63. 
[21] Baharun, H. (2017). Total Moral Quality: A New Approach for Character Education in Pesantren. Ulumuna, 21(1), 57-80.

[22] Chowdhury, M. (2018). Emphasizing morals, values, ethics, and character education in science education and science teaching. MOJES: Malaysian Online Journal of Educational Sciences, 4(2), 1-16.

[23] Yusoff, M. Z. M., \& Hamzah, A. (2015). Direction of moral education teacher to enrich character education. Jurnal Ilmiah Peuradeun, 3(1), 119-132.

[24] Morales-Sánchez, R., \& Cabello-Medina, C. (2013). The role of four universal moral competencies in ethical decision-making. Journal of Business Ethics, 116(4), 717-734.

[25] Pizarro, D. A., \& Tannenbaum, D. (2012). Bringing character back: How the motivation to evaluate character influences judgments of moral blame. 